Yurii Malakhovskyi, Associate Professor, $\mathrm{PhD}$ in Economics

Ali Kanso, intern

Sniganna Kovalenko

Central Ukrainian National Technical University, Kropyvnytskyi, Ukraine

\title{
Social Capital: Theoretical Foundations of Identification and Regulation
}

The article is devoted to solving the problem of the identification and regulation of the national economy' social capital as the totality of the structured social and economic relations, based on the mutual informal institutions (norms and values), the compliance of which brings the benefit to the subjects of the relations in the form of the social rent, expressing the size of savings from restructuring of the institutional institutions and organizations on the basis of the clear specification of property rights, creation of the organizational structures, that ensure their effective exchange, comparison and saving of costs, arising in the process. In the basis of the state regulation of the social capital relies the process of the planned development of its main elements - trust, norms, rules, social relations, goodwill, culture.

social capital, functions of social capital, regulation of social capital

Ю.В. Малаховский, доц., канд. экон. наук

А.А. Кансо, стажер

С.В. Коваленко

Центральноукраинский нациинальный технический университет, Кропивницкий, Украина

Социальный капитал: теоретические основы идентификации и регулирования

Статья посвящена решению проблемы идентификации и регулирования социального капитала национальной экономики как совокупности структурированных социально-экономических отношений, основанных на взаимно признанных неформальных институтах (нормах и ценностях), соблюдение которых приносит пользу субъектам отношений в форме социальной ренты, которая выражает размер сбережений от реструктуризации институциональных учреждений и организаций на основе четкой спецификации прав собственности, создания организационных структур, обеспечивающих их эффективное обмен, сравнение и экономию расходов, возникающих в ходе этого процесса. В основу государственного регулирования социального капитала полагается процесс планомерного развития его основных элементов - доверия, норм, правил, социальных связей, деловой репутации, культуры

социальный капитал, функции социального капитала, регулирования социального капитала

Statement of the problem. The category "capital" is one of the most widely used in modern framework fundamental theoretical and applied practical research. Its application requires the use of a balanced multi-component and multi-subject historical and logical approach. The impact of certain phases of the development of social relations on understanding of the essence of this basic concept has significantly influenced the development of a modern dynamic and cognitive approach to understanding capital. Its definition continues to be specified and renewed due to the implementation of sophisticated accents and changing priorities in the approaches to formulating scientific viewpoints of different authors.

The social capital of the national economy - the totality of the structured social and economic relations, based on the mutual informal institutions (norms and values), the compliance of which brings the benefit to the subjects of the relations in the form of the social rent, expressing the size of savings from restructuring of the institutional institutions and organizations on the basis of the clear specification of property rights, creation of the organizational structures, that ensure their effective exchange, comparison and saving of costs, arising in the process. Functions of social capital: the ability to reduce the transaction

(C) Yurii Malakhovskyi, Ali Kanso, Sniganna Kovalenko, 2019 
costs by increasing the level of trust; the provision of access of the subjects to the goods and values, the significant increasing of the value of the existing resources, reducing of the costs, due to the access to them; facilitating access, overcoming the phenomena of the imperfection of the market information, its inaccessibility, secrecy, unilateralism; increasing the confidence to the state institutions, the consolidation of the society, increasing the level of the social stability, the acceleration of the economic development.

The growth of the social capital has as consequence the reduction of the "friction forces in the economy", expressed in the economy of the transaction costs, savings from the reconstructing institutions and organizations based on the clear specification of property rights, creation of the organizational structures to ensure their effective exchange, comparison and cost savings arising in this process.

Analysis of recent researches and publications. The first approach to study the subject as a scientific research was carried out by Hanifan in 1916 [14]. He studied concepts relevant to the category, their meaning and influence on the processes of social development.

Numerous researchers who study the economic nature of social capital of national economy (SCNE) phenomenon can be conditionally assigned to one of the three directions:

- Bourdieu's followers understand its essence mostly as “.... a set of real or potential resources that are associated with a stable network of [durable networks] more or less institutionalized relationships of mutual acquaintance and recognition... or, in other words, group membership" [1]. The value of social capital (SC) is seen in the usefulness when it provides certain benefits to its consumer. The scientist calls these kinds of resources "the ability to dispose necessary conditions and prerequisites for practice; ... the structure of domination and power over other agents" [1], linking them with the possibility of strengthening the position of a person in society as a whole, developing other types of capital, increasing their position in the network, prestige, influence and importance. The peculiar viewpoint of the followers of this strand of research is that they investigate the results or consequences of using capital as an individual characteristic for a particular personality, that is $\mathrm{SC}$ carrier;

- Coleman's followers [3] do not specify a single definition of the category. They focus on the functions and usefulness of SC as the unity of personalized human and group (organization) resources. In contrast to Bourdieu's position, the implementation of SC is associated not only with positioning itself in society, but mostly with the function of convenience of using it as a public resource, public welfare in order to facilitate personal activity of economic entity at macro-, meso- and microeconomic levels of management. That is why they distinguish SC sources, such as trust and establishing relationships, the descent of man and the history of his or her descent. Regardless of the point of view on understanding the SC essence, it should be acknowledged that followers of all aspects of the study of this phenomenon are unconditionally acknowledge SCNE as the source of power and welfare; it originates and exists only under the conditions of mutual relations among people;

- Fukuyama's followers focus on the network of moral relationships "trust among groups of individual agents who share informal norms or values ... $<\ldots>$ norms and values can range from simple principle of reciprocity between two friends to the complex value systems created by organized religions ..." [9]. The followers of this scientific field consider SCNE as public resource and define it as informal norms and values. They understand it as a property not so much of an individual, but as a resource for the development of associations and entire states. The source of the SC is natural co-operation of people, their integration into selfgoverning groups to collectively address important issues based on compliance with obligations, compliance with norms of reciprocity, and avoidance of opportunistic behaviour. 
The implementation of an alternative approach allows classifying options for determining the content of SC from the standpoint of identifying the ultimate goal of functioning that is the formation of social networks, social norms and values.

A number of researchers of the processes of state regulation of increasing SCNE have noted the peculiarities that extend the study of its significant differences in comparison with the alternative types of capital resources/assets of the steady increase of individual and collective welfare of the nation:

- SCNE system of elements as an object of forecasting/design requires definite arrangement according to certain classification features (Fig. 1);

- social investment (in the broad sense of the word) occurs at the same time, in the form of funding the formation of social capitl, human capital, and transitional/mixed forms of these two types of capital;

- it is necessary to find out the nature of the investments in SCNE in terms of characteristic features of the process of transformation of investment expenditures into expenses for the formation of profitable intangible (intellectual interpersonal) assets, which are expected to pay off in future. Counterparties that incur the cost of forming SCNE tend to assume predominantly moral obligations. In future, the realization of the obligations, with high probability, but not automatically, generates counter-obligations because of the potential for their managers to obtain additional benefits;

- conscious regulation of investing processes requires logical sequence of determining the value of investments in SCNE, its transfer to gross costs, differentiated calculation of the efficiency of profitable (in the process of comparing the value of property titles or specific goods with incurred costs), as well as unprofitable investments (patronage, mutual help, volunteer work, etc.);

- a clear distinction should be made between mandatory social costs of the institutional sector of governmental authorities, which are carried out by budgetary funds, and public expenditures that are legitimately regarded as social investments;

- when making social investments, account should be taken of the non-static unbalanced and complex cause and effect chain of realization of the whole set of social phenomena with forced or unforced violations of the established logic of events that is generated by the society as a whole. At the same time, there is a high capacity of meaningful and meaningless events; the number of external manifestations of social phenomena is very large and ambiguously interpreted. All of them can be violated in one way or another, except for sociological. The model should include the results of psychological, political, economic, medical, pedagogical research and the like;

- the established approaches to the measurement of SCNE are considered unsatisfactory and outdated, that rapidly lose their relevance because they do not reflect flows in the value of capital; instead, an approach (for example, a cognitive approach to modeling J. Forrester's system dynamics [15]) is proposed, according to which SCNE elements are treated not as absolutes with qualitatively implicit changes, but as relevant which include the detected changes in the scale of the phenomenon;

- for updating methods of forecasting and programming of a set of processes in the environment of SCNE functioning, as a complex system with nonlinear feedbacks, methods of system dynamics (with graphical diagrams of causal relationships and global effects of one parameter on the other in time) are used $[13 ; 10 ; 11]$, with some caveats. G. Gordon's Discrete Event Programming (GPSP (Global Purpose Simulation System)) method, as well as the latest techniques of agent-based model (ABM) bottom-up simulation $[6 ; 7 ; 18 ; 19]$, and the influence of performance agents on the global behaviour of the system as a whole; 


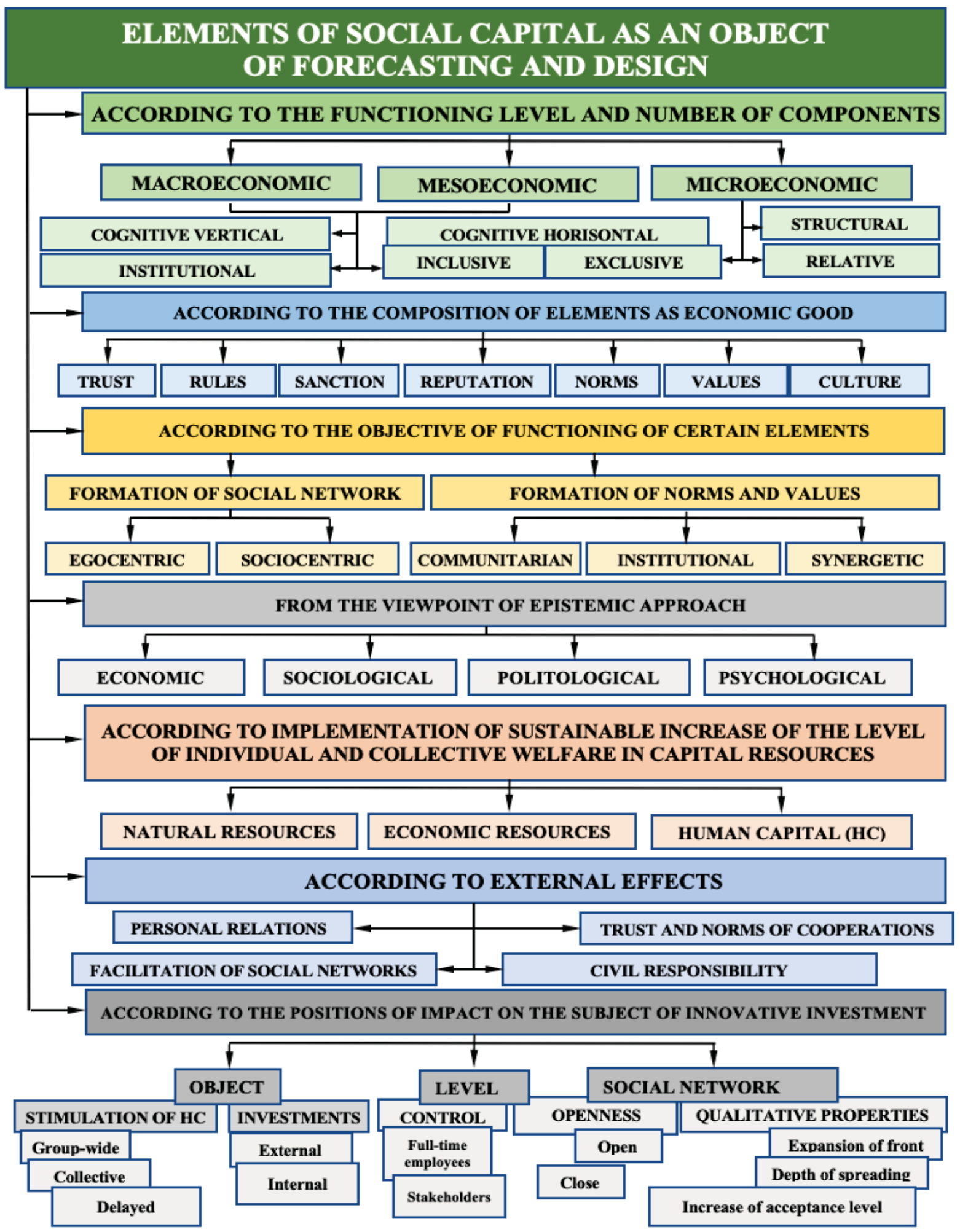

Figure 1 - SCNE elements as an object of forecasting and programming

Note: HC - human capital

Source: summarized by the author on the basis of $[1 ; 3 ; 9 ; 21]$. 
- the study of transactional costs of the national economy hold a special place in the studies. The decrease of the costs actually serves as a source of social investment returns in the amount of the increase in the value of SCNE;

- a detailed study of the cycle of groups of cause and effect relationships of transformation processes in the process of simulation of SCNE, as well as the behaviour of decentralized agents involved in its formation is necessary. It is also necessary to study the features of manifestation of main prototypes of relations among individuals and social groups that cause a direct impact on the formation of SCNE. The causes of uncertainty in social investments, institutional environment of social capital formation in all its various forms, functional forms, and multivariate identifying promising strategies for transformation of social capital are also an important field for investigation.

Statement of the objective. The aims of publication are to justify and develop theoretical positions, methodological approaches and scientific and practical recommendations on regulation (forecasting and designing) of the social capital at the level of the national economy.

The main material. Basic model of SC micro-level [17] considers it as a set of functioning of three components. The issues of strength of the group members' connections with other individuals, the inclusion of individuals in social networks, the degree of density of the social networks are considered in the process of studying structural component. Cognitive component, which is a passive reflection of organizational culture, consists of language, thesaurus and narratives shared by the group members. Relational component is represented by trust, social norms, level of identification with the group, commitments and expectations.

The cognitive component also includes the relative component. In this case, it consists of norms, values, attitudes, beliefs of a person facilitating joint activity, perception of help and support, reciprocity, willingness to share resources and trust within the group.

Cognitive SC has two levels: individual level as a basic willingness to cooperate and group level as a successful collective interaction. The preconditions to form SC at the personal level are: the willingness to cooperate (the tendency to trust others, help, care for the well-being of the environment, take on social responsibility, etc.), the willingness to defend their interests (non-aggressive confidence (persistence) in the process of self-interest, the obligation of mutual services such as assertiveness, cognitive flexibility, ability to adapt and interact effectively with the workgroup.

Examples of complete, valid, open methods of measuring cognitive SC at the community level of neighborhoods that compactly reside in a particular territory (neighborhoods, satellite cities, villages, urban settlements, etc.) are the 7-scale A-SCAT (Adopted Social Capital Assessment Tool) and the 8-scale ONYX. Based on the results of the studies, graphs of relationships between the scales are displayed, showing level of correlation $r$ and the level of their significance $p$. Cognitive SC of the group level is formed under the condition of high level of cognitive SC of individual level, as well as understanding of the collective goals by the members of the work groups and the availability of agreement regarding the means to achieve them.

The macro-level SC provides formal relationships and structures that include the rule of law, legal system, type of political regime, level of decentralization, and the level of participation in the political process. It should be noted that a unified methodology for measuring SC level and "generalized confidence" at the macroeconomic level has not yet been developed. This is explained by the fact that misunderstanding permeates not only the sphere of calculation of the components of the final formula and the dimension of the results, but also their interpretation. Recent methods can only provide the coefficient with a range of normative values that allow formulating judgments about the "manifestation level" of SC in 
society, the extent to which citizens are involved in social networks and the nature of their interaction.

The main methods of quantitative measurement of SC are to calculate its level on the basis of "distal" and "proximal" Putnam indicators, SOCAT method, Fukuyama "confidence radius", and rating index.

The following definitions include more detailed characteristics of SC types:

- bonding social capital (BoSC) includes social networks of micro- and cognitive levels of closely and strongly interconnected individuals (within a family, a highly identical homogeneous ethnic group) of homogeneous groups formed and used to maximize daily life easiness ("getting by in life") [22]. The sources of information on the structure, origin and quality of personal social connections within the framework of the formation of objects of SC are the results of conducting basic social research of the economical entities, the analysis of self-centered social networks, etc. The mechanisms of BoSc implementation are the provision of social (emotional, instrumental, evaluative and informational) support, normative guidance through manifestation of standards of behavior within the group, demonstration of potential roles in real life, personal contacts, psychological and physiological factors;

- bridging social capital (BrSC) are social networks of remote individuals who are poorly connected through cross-cutting, more meaningful than family, relationships (business partnerships, acquaintances, handshake acquaintances, friends from other ethnic groups), which can be used to get on in life ("getting ahead"), to organize a "social lift" channel [16];

- linking social capital (LSC) includes social networks of cohesive individuals who occupy different positions in hierarchical structures. Their membership facilitates access to get support from official institutions [20].

Large-scale measurements of the parameters of SC functioning at the meso- and macro-levels of the national economy have recently been carried out with sufficient frequency.

Turning to the practical plane of quantitative measurement and regulation of the SCNE, it should be noted that one of the most universally representative indicators of its functioning in society is generalized (consolidated) trust.

Unlike the specific in-group trust, directed onto certain situations or groups, the generalized out-group trust can be defined as confidence in the rightness, honesty, sincerity of the people as a whole outside the context of a particular situation, personal acquaintance, ethnicity, religious or other affiliation. Generally, the concept of trust is an absolute polysemic homonym and contains the following meanings: structure, disposition, attitude, feelings, expectations, faith, intention [2].

Higher levels of credibility are associated with a higher standard of living, the effective functioning of political, public and economic institutions, tolerance and subjective well-being.

Strategic trends for improving the efficiency of the state regulation of SCNE were formulated by us in order to achieve the UN Sustainable Development Goals [8; 12].

Having been substantiated by previous studies, SCNE is defined as a set of structured socio-economic relations based on mutually recognized informal institutions (norms and values). Compliance with the norms and values benefits the subjects of relations in the form of social rent, expressing the amount of savings from restructuring institutional institutions and organizations based on a clear specification of ownership rights, creation of organizational structures to ensure their effective exchange, comparison and cost savings that arise during consideration of its impact on the formation of welfare of the nation.

The institutional environment of the SCNE is a set of political, legislative, economic and socio-cultural factors for the formation of its regulatory, supportive and cognitive 
environments, purposeful regulation by means of managerial, psychological and social technologies as a set of processes and methods of multiple application of governmental authorities of the symbolic capital of conditional values that provides "in advance" generalized trust to its carrier from the side of the target audience in the face of the institutional object (agent) and institutional sector of the national economy. It is based on the use of the unconditional positive reputation potential of the state in order to achieve commercial and non-economic benefits at meso- and macro-levels of transformational modernization of the national economy due to the deliberate use of "soft incentive force" to accept civilization values of the subject of influence.

A characteristic feature of the strategic reform of institutional environment for the deployment of SCNE in the context of modern economy is that it is against the backdrop of the phenomena of transformational modernization that are linked to the latest trends in social development.

State regulation of the institutional environment of the SCNE is one of the strategic trends of practical implementation of the provisions of neo-institutional theory. It takes into account the peculiarities of changing dynamics of the architectural structure of the national economy in time. Unlike the mathematically rigorous neoclassical theory of modeling general equilibrium in statics, which took scientific and technical progress as the socio-economic development at first, later it was investment in human capital, the neo-institutional theory modifies it, while remaining at the fundamental positions of scarcity of resources and competition. It broadly involves analytical tools of microeconomic analysis of neoclassical theory.

Changes in the economy are an ever-increasing process as a result of daily choices by individuals, entrepreneurs, and organizations of economic exchange that pursue the goal of improving their situation. The main long-term source of change in modern age is the knowledge of individuals/entrepreneurs who create organizations. The speed of economic change depends on the intensity of the process of cognition, and their orientation depends on the knowledge-driven expectations of benefits that are associated with the acquisition of knowledge.

The strategic direction of increasing the efficiency of the state regulation of SCNE is the implementation of its compliance-control procedures at the institutional and organizational levels. The residual attention is paid to its individual level. At the institutional level it is a matter of patterns of development, selection and change of social institutions, the effectiveness of procedures of "posing to society" positive and negative incentives that direct people's behaviour in a certain direction, eliminate entropy, transform social environment into less uncertain. At the organizational level we speak about the choice or certain organizational forms, depending on the nature of the existing institutional environment. At each level, the interaction of institutional objects (agents) of the national economy is connected with inevitable costs and losses, which have the generic name of the transnational expenditures of the national economy.

The subject of regulatory application of neo-institutional theory, as a coherent conglomerate of ideas for the formation and measurement of the SCNE, is:

- broad concept of institutions (informal/formal rules, mechanisms of coercion to comply with the rules), factors influencing institutional dynamics (changes in the structure of relative prices due to the technological progress, opening new markets, population growth; ideology - subjective models which individuals perceive and evaluate the surrounding world), institutional environment - fundamental political, social and legal rules under which the processes of production and exchange take place (stating the main reasons for preservation of inefficient institutions) [5]; 
- institutions of public sphere (theories of rational public and social choice);

- institutions of private sphere, securing property rights and their reliable protection at meso- and macroeconomic levels (the theory of property rights);

- organizational forms of cooperation among individuals within the generally recognized "rules of the game" (theory of "agent-agent" (agency theory));

- positive theory of construction of organizational schemes for the implementation of agency relations in the field of "separation of property (interests of principals) from the control of agents (hired managers)" at the stages of conclusion of agreements;

- theory of transactional expenditures of the national economy in the sphere of their application at the stage of contract execution, determination of quantity and quality of goods/services transferred at the stage of implementation of the agreement;

- normative theory of design of organizational schemes for optimal risk allocation among market agents (mechanism design theory);

- study of regulatory structures (governance structure) for each class of agreements that minimize transactional expenditures of the national economy. These are special mechanisms used to assess the behaviour of contractual parties, to resolve emerging disputes, adapt to unexpected changes, apply sanctions to violators, which involves a combination of assumptions of unlimited rationality and opportunism.

Awareness of the importance of social capital of the national economy in the market economic mechanism and formation of well-being of the nation require realization of a complex theoretical model of the reproductive approach to its functioning. At the same time, the efficiency of state regulation in the process of formulating strategic directions should be increased.

The formulated approach measures up the requirements for:

- substantiation of a systematic approach to the revelation of the essence of the economic phenomenon, its renewal and development. It is based on the sequential change of stages of reproduction, correspondence of the content and public form of manifestation, ensuring the conditions of transition from simple to extended reproduction of functioning conditions;

- determination of the essence of the phenomenon through the system of social and economic, social-legal, organizational, economic and market relations. They describe relatively separate but process-related subsystems and arise among entities that are direct carriers of capital assets, as well as the among entities that express relationships regarding their self-renewal and growth in the interests of achieving the ultimate goal of functioning. There is also generalization and complementation of characteristic features and functions in which the essence of the positive potential of capital assets is revealed;

- definition of the structure of elements that express the content of the social and economic category of SCNE in the composition of the objects that characterize material side of deployment on the one hand. Definition of entities, as well as the system of economic relations among them for the reproduction and development of capital assets, reflecting the public side of functioning on the other hand;

- substantiation of the material content of SCNE as an economic phenomenon, applying the principle of "process-result" to the dynamics of its change. In accordance with the principle its reproduction is considered as a process of constant restoration of the ability of entities to produce collective capital assets (formation, distribution, exchange and the use of elements of BoSC, BrSc, LSC) and, as a result, the ability to perform productive social functions assigned to it. The volumes and directions of socially recognized useful costs and expenditures that characterize its production as a process of intermediate consumption of 
institutional units of the national economy in the course of shaping the welfare of the nation (value of comparative indices of the achieved level of development) are determined;

- identification and characterization of the structures of the system of economic relations of SCNE reproduction, which includes subsystems (formation as a public good; determining the value of assets as a marketable product; distribution, exchange and use as a co-evolutionary social market network well-being). It also includes relations of formation, distribution, exchange and use that form a single coherent system on the basis of their interconnection; the system of measures for their improvement, which correspond to the stages of capital reproduction and subsystems of relations of the essence is suggested. They are: social and economic (development and emergence of new forms of expression of property relations, interaction of economic interests of among entities, etc.); social and legal (creation of safe and favourable conditions for the formation and improvement of legislation, etc.); organizational and economic (promoting the introduction of new forms and methods of social capital formation, development of cooperation and division of labour, etc.); market (formation and development of competitive environment, achievement of sustainable development goals by ensuring and institutionalizing multiple equilibrium of social development, smoothing inequalities, enhancing pro-social and eliminating anti-social instances of asset use, etc.);

- disclosure and purposeful improvement of the structure of the mechanism for regulating economic relations of SC reproduction. The structure includes the totality of its hierarchical components (micro-, meso- and macroeconomic level), varieties (value orientation, direct social impact, limited solidarity and inductive trust). Each of them consists of the elements such as entities, objects, methods and instruments of regulation. The functions of each element of the mechanism are defined: level of the household activity (formation of BoSC), level of non-financial corporation, regional (sectoral), national innovative ecosystems (formation of BrSc, LSC), marketing function (planning, coordination, stimulation, control, information, combination of separate functions in the process of programming and forecasting).

In the basis of forecasting and designing as specific mechanisms of the state regulation of the social capital relies the process of the planned development of its main elements - trust, norms, rules, social relations, goodwill, culture. These processes is based on the principles of the formation of the strategical goals of the priority directions of the social and economic policy - scientific justification, consistency, adequacy, alternative (variance), efficiency (optimality), continuity in the process of developing target, comprehensive programs - system totality of the oriented in space and time, coherent in content, terms, artists, provided with resources of measures, aimed at the development of its main elements to save costs in the transaction sector of the national economy.

Conclusions and prospects for further researchers. The basis for the development of practical directions for improving the efficiency of SCNE formation and its functioning includes our interpreted and adapted to practical needs of controlled regulation of the national economy theoretical principles of functioning in modern conditions formulated by Veblen T. [23] and the researcher of social and legal aspects Commons J.R. [4], as well as the factors of the transformational renovation of the SCNE elements under the conditions of modernization of current economy.

In general, they are formulated as follows:

- collective economic interests, the carriers of which are technocrats-intellectuals engaged in industry, who are interested to increase labor productivity and its efficiency. The sphere of functioning of real capital (industry) by itself does not contain social antagonisms. 
Public contradictions and conflicts have to do with the functioning of capital in the financial sector, fictitious capital and its pressure on the industry;

- the task of economists is to study the norms, customs and their evolution in order to explain the decisions made by economic agents at different times and under different circumstances;

- the basis of institutionalism are neo-orthodox theories, which assume the presence of hedonistic motives of human behaviour, formulate alternatives to individualistic competition, explore other problems of economic theory;

- the content of regulatory influence on the processes of realization of economic phenomena (agreements) for the dominance of the institutional economy is the wilful introduction of the influence of collective institutions on the control of individual actions on the basis of social psychology and law in order to achieve acceptable for society agreements (market, administrative, distribution) contradictions of the economic system on the way of establishing final amount of "reasonable value";

- the principles of economic behaviour are performance, rarity, evaluation of future well-being. Productivity is related to the "technical concept" of cost value, which is determined by the administrative type of transactions, but is also determined by the future usefulness of the assets, their rarity, value of the stock, future net income from the use of a particular type of capital. "Fair value", in addition to what is said, is also determined by taking into account the costs that are interpreted as a psychological internal counteraction to incentives to act in a certain way;

- the basis for establishing "reasonable value", providing an objective quantitative public assessment of the value of goods in order to ensure the stability of society are the psychological motives of activity, agreements and culture as main concepts of modern political economy.

\section{References}

1. Bourdieu, P. (1986). Forms of capital. Handbook of Theory and Research for the Sociology of Education. J. Richardson (Ed.). Westport, CT: Greenwood.

2. Carillo Alvarez, E., \& Riera-Romani, J. (2017). Measuring social capital: further insights. Gaceta Sanitaria. Jan - Feb, 31(1), 57-61.

3. Coleman, J.S. (1994). Foundations of Social Theory. Harvard University Press.

4. Commons, J.R. (1934). Institutional economics: Its place in political economy. N.Y.: McMillan. Repr., Madison: The University of Wisconsin Press.

5. Commons, J.R., Parsons, K.H., \& Perlman, S. (1950). The Economics of Collective Action. New York: Macmillan.

6. Conte, R., Sichman, J.S., \& Gilbert, N. (1998). Multi-Agent systems and Agent-Based Simulation: First International Workshop, MABS'98 (Paris, France, July 4-6, 1998, Proceeding (Lecture Notes in Computer Science (1534), Band 1534. Springer.

7. Delli Gatti, D. (Eds.). (2018). Agent-based models in economics: A Toolkit. Cambridge University Press.

8. Fountain, J.E. (1998). Social capital: a key enabler of innovation. Investing in Research and Innovation Policy: Creating a Research and Innovation Policy that Works. L.M. Branscomb, J.H. Keller (Eds.). Cambridge: MIT Press.

9. Fukuyama, F. (2000). Social Capital and Civil Society. IMF Conference on Second Generation Reforms (Nov. 8-9, 1999). Washington, D.C.: IMF Working Paper. www.imf.org. Retrieved from https://www.imf.org/external/pubs/ft/wp/2000/wp0074.pdf

10. Gilbert, N., \& Stoneman, P. (2015). Research social life. Willey: Sage Publication.

11. Gilbert, N., \& Troitzsch, K.G. (2005). Simulation for the Social Scientist. Open University press.

12. Halliwell, J.F., Layard, R., \& Sachs, J.D. (2019). World Happiness Report. s3.amazonaws.com. Retrieved from https:// s3.amazonaws.com/happiness-report/2019/WHR19.pdf.

13. Hamill, L., \& Gilbert, N. (2016). Agent-based modeling in economics. Willey: University of Surrey; Centre for research in social simulation (CRESS). 
14. Hanifan, L. J. (1916). The Rural School Community Centre. Annals of American Academy of Political and Social Science, Vol. 67, New Possibilities in Education (Sep., 1916), 130-138.

15. Kawamoto, K., \& Kim, K. (2019). Efficiencies of bonding, bridging and linking social capital: Cleaning up after disasters in Japan. International Journal of disaster risk reduction, Vol. 33, 64-73.

16. Mpanje, D., Gibbons, P., \& McDermott, R. (2018). Social capital in vulnerable urban settings: an analytical framework. Journal of International Humanitarian Action, Vol. 3 Retrieved from https://doi.org/10.1186/s41018-018-0032-9

17. Nahapiet, J., \& Ghoshal, S. (1998). Social capital, intellectual capital, and the organizational advantage. Academy of Management. Academy of Management Review. Vol. 23, No. 2 (Apr., 1998), 242-266.

18. Railsback, S.F., \& Grimm, V. (2011). Agent-based and Individual-based modeling: A Practical Introduction. Princeton University Press.

19. Ramzi, S., Troitzsch, K.G., \& Gilbert, N. (2000). Tools and Techniques for Social Science Simulation. Physical-Verlag Heidelberg.

20. Rui, J. R., Covert, J. M., Stefanone, M.A., \& Mukherjee, T. (2014). A Communication Multiplexity Approach to Social Capital: On- and Offline Communication and Self-Esteem. Social Science Computer Review. Vol. 33, Issue 4, 498-518.

21. Scrivens, K., \& Smith, C. (2013). Four Interpretations of Social Capital: An Agenda for Measurement. OECD Statistics Working Papers. Paris: OECD Publishing. dx.doi.org. Retrieved from http://dx.doi.org/10.1787/5jzbcx010wmt-en.

22. Siegler, V. (2015). Measuring National Well-being - An Analysis of Social Capital in UK. Office for National Statistics Conference on Social Capital and Poverty Reduction. www.researchgate.net. Retrieved from https://www.researchgate.net/publication/281293211_Measuring_National_Well-being_An_Analysis_of_Social_Capital_in_the_UK_2015_Office_for_National_Statistics

23. Veblen, T. (1924). The theory of the leisure class. An economy study of institution. New York: B.W. Huebsch.

Ю.В. Малаховський, доц., канд. екон. наук

А.А. Кансо, стажист

С.В. Коваленко

Центральноукраӥнський національний технічний університет, Кропивницький, Украӥна

\section{Соціальний капітал: теоретичні основи ідентифікації та регулювання}

Метою дослідження $€$ вирішення проблеми ідентифікації та регулювання соціального капіталу національної економіки як сукупності структурованих соціально-економічних відносин, заснованих на взаємно визнаних неформальних інститутах (нормах та цінностях), дотримання яких приносить користь суб'єктам відносин у формі соціальної ренти, яка виражає розмір заощаджень від реструктуризації інституційних установ та організацій на основі чіткої специфікації прав власності, створення організаційних структур, що забезпечують їх ефективний обмін, порівняння та економію витрат, що виникають у ході цього процесу.

Регулювання соціального капіталу $\epsilon$ стратегічним напрямом запровадження заходів управлінського впливу органів виконавчої влади на комплекс міжперсональних зв'язків, які використовуються 3 метою організації процесів безпосереднього виробництва суспільно значимих товарів та послуг, а також генерування широкого кола добре продуманих результатів колективної діяльності, пов'язаних з поширенням у суспільстві стандартів довіри, репутації, правил, норм, санкцій, цінностей, культури співвиробництва товарів та цінностей персонального та колективного споживання.

Прогнозування стану, структури, перспектив зростання вартості елементів соціального капіталу здійснюється на основі принципів системності, аналогічності, природної специфічності, цілеспрямованості, наукового обгрунтування, оптимального опису об'єкта, його інформаційної єдності, адекватності об' єктивним закономірностям розвитку, послідовного подолання невизначеності, аналогічності, альтернативності варіантів зміни траєкторій розвитку явища у майбутньому, ефективності, безперервності формування стратегічних цілей розвитку. Програмування соціального капіталу розроблення системної сукупності зорієнтованих в просторі та часі, узгоджених за змістом, термінами, виконавцями, забезпечених ресурсами заходів регулятивного впливу, що спрямовані на збільшення продуктивних активів, які є вбудованими, обмежено доступними та отримуваними за рахунок участі у мережевих взаєминах з метою підвищення рівня персонального та колективного добробуту його носіїв, який сприймається суспільством як отриманий у прийнятний спосіб.

соціальний капітал, функції соціального капіталу, регулювання соціального капіталу 